the age of criminal responsibility» as participants in criminal proceedings is ignored by the current criminal procedural law. Formally, the status of a defense party in a criminal proceeding is associated with a notification of a person suspected of committing a crime. However, the legislation does not provide for such a communication concerning persons who have committed a socially dangerous act (because of non-achievement of the age of criminal responsibility are not the subjects of a crime). And, accordingly, the status of such persons is not definitively defined. In some bodies, a person who has not reached the age of criminal responsibility, is being examined and questioned as a witness, no suspicion is reported. The uncertainty of the procedural status of such a child and his legal representatives, the defense counsel (lawyer) complicates the realization of full protection of the rights of these persons. The emphasis is placed on the need to consolidate the legal status of such persons in the criminal procedural law, as well as the introduction of a new institution - notification of suspicion of committing a socially dangerous act of persons who have not reached the age of criminal responsibility. The conclusions suggest a draft of new norms to the Criminal Procedural Code of Ukraine.

Key words: children, socially dangerous act, criminal proceedings, legal status, compulsory educational measures, juvenile justice.

DOI https://doi.org/10.33766/2524-0323.86.115-125

УДК 342.56:342.57

I. М. Кравченко,

викладач кафедри загально-правових дисциплін

Дніпровського гуманітарного університету

(м. Дніпро, Україна)

e-mail: mpv12@i.ua

iD https://orcid.org/0000-0001-8693-1428

\title{
ПОНЯТТЯ ТА ЗМІСТ ГРОМАДСЬКОГО КОНТРОЛЮ НАД ДІЯЛЬНІСТЮ АДМІНІСТРАТИВНИХ СУДІВ
}

Стаття присвячена аналізу поняття, сутності та змісту громадського контролю як самостійного напрямку взаємодії адміністративних судів із громадськістю. Наведено поняття громадського контролю над адміністративними судами. Визначені принципи здійснення громадського контролю над адміністративними судами. Встановлені форми здійснення громадського контролю над адміністративними судами. Розкриті методи проведення громадського контролю над адміністративними судами. Виокремленні проблемні питання здійснення громадського контролю над адміністративними судами, а також визначені напрямки вдосконалення громадського контролю над адміністративними судами.

Ключові слова: адміністративний суд, громадянське суспільство, громадський контроль, державна влада, метод громадського контролю, судова влада, форма громадського контролю

Постановка проблеми. Запорукою стримування держави, контролю над владою виступає громадянське суспільство, оскільки державна влада завжди тяжіє до абсолюту. Суспільство постійно потребує існування важелів 
«противаг» щодо держави. Порушення такого балансу призводить зазвичай до політики етатизму - надмірного втручання державних органів влади в справи суспільства, бюрократичної опіки й регламентації суспільного життя, обмеження прав та свобод особистості. Саме тому в дійсно демократичному суспільстві повинні існувати механізми громадського контролю за діяльністю влади, у тому числі судової. Ця теза базується на прозорості та відкритості всієї системи функціонування владних інститутів, їх відповідного правового забезпечення, що в кінцевому підсумку унеможливлює приховування «невигідної» інформації, завдяки чому контролюючими за цих умов стає переважна більшість членів суспільства. Проте, на жаль, можливість громадського контролю не завжди знаходить адекватне відбиття в офіційних правових документах. Саме тому правовий взаємозв'язок між державою і громадянським суспільством є поки що недостатньо ефективним. Таким чином, створення дієвого механізму співпраці влади та громадськості можливе через налагодження стабільних та ефективних зв'язків із громадськістю, однією з результативних форм яких $є$ громадський контроль. Саме він по відношенню судової влади, у тому числі щодо адміністративних судів, здатен дати поштовх до створення ефективної та дійсно справедливої судової системи. Тобто, дослідження громадського контролю адміністративних судів як одного 3 напрямків налагодження взаємодії громадськості та судової влади, відновлення довіри до судової системи, визначення його принципів, методів і форм, його ролі для демократизації суспільства, а також пошук можливих меж набуває сьогодні особливої актуальності.

Аналіз останніх досліджень і публікацій. Поняття та сутність контролю як соціального явища обгрунтовано у дослідженнях В. Авер'янова, I. Голосніченка, В. Горшеньова, О. Данільяна, М. Кельмана та ін. Державний контроль вивчали Д. Бахрах, Ю. Битяк, В. Гаращук, Є. Додін, Р. Калюжний, С. Ківалов, В. Колпаков, В. Сіренко, Ю. Шемшученко та ін. Різноманітним аспектам функціонування громадського контролю присвячено наукові праці В. Афанасьєва, А. Балкова, С. Денисюка, М. Іжи, А. Крупника, С. Кушнір, І. Попової, О. Радченка, Л. Рогатіної та ін. Проте, незважаючи на наявний значний доробок вітчизняних та зарубіжних учених, слід констатувати, що проблема громадського контролю судової влади в цілому та адміністративних судів зокрема, визначення його ролі у демократизації суспільства ще потребує всебічного дослідження.

Формування цілей. Метою статті є проведення аналізу поняття та змісту громадського контролю над діяльністю адміністративних судів в Україні.

Виклад основного матеріалу. У більшості випадків контролюючу діяльність громадськості у сфері державного будівництва називають громадським контролем [1, с. 13], хоча в науковій літературі трапляються й інші назви [2, с. 68], що суттево не впливає на визначення сутності даного явища. Без сумніву, громадський контроль $є$ важливим соціальним інститутом організації суспільних відносин у частині консолідації зусиль 
органів державної влади та громадських організацій, спрямованих на раціоналізацію соціального буття, збереження цілісності та соціокультурної самобутності суспільства. Громадський контроль - це один із видів соціального контролю, що здійснюється громадськими об'єднаннями та безпосередньо самими громадянами, він є важливим засобом реалізації народовладдя та дієвим способом залучення населення до управлінських функцій. Вагому роль у здійсненні громадського контролю відіграє громадськість [3].

1. Поняття громадянського контролю над діяльністю адміністративних судів. Дієвий громадський контроль у демократичному суспільстві розглядається як цілеспрямований та вагомий вплив соціальних суб'єктів на поведінку агентів соціальної взаємодії. В. М. Олійник визначає громадський контроль як «систему відносин громадянського суспільства 3 державою, яка грунтується на підзвітності органів державної виконавчої влади органам державної законодавчої влади (парламентський контроль) та недержавним структурам («третьому секторові» та засобам масової інформації)» [4, с. 90]. Такий підхід вважаємо не зовсім прийнятним. Якщо перша частина дефініції сумнівів не викликає, дійсно громадський контроль, як певна діяльність, формує систему відносин держави та громадянського суспільства, то в частині визначення суб'єктів такого контролю погодитися не можна. Суб'єктами громадського контролю можуть бути, виходячи 3 першої частини визначення, інститути громадянського суспільства, їх структурні підрозділи, соціальні суб'єкти і, в першу чергу, самі громадяни. Що стосується органів державної влади (і виконавчої, і законодавчої, і судової), то вони можуть бути тільки об'єктами громадського контролю, адже саме їх діяльність оцінюється з точки зору ії відповідності нормам Конституції України, законів України, інших актів законодавства.

2. Сутність громадянського контролю над діяльністю адміністративних судів. Хоча в словниках поняття «контроль» тлумачиться як «перевірка, облік, нагляд», узагальнюючи наявні підходи до визначення громадського контролю як такого, вважаємо, що більш правильно громадський контроль судової влади слід визначати як діяльність громадськості $з$ оцінювання виконання судами своїх повноважень, визначення ефективності їх функціонування. Що стосується цілей громадського контролю, то важливо підкреслити, що він повинен здійснюватися, у першу чергу, з метою захисту прав людини. Особистість, ії всебічний розвиток, добробут, права та свободи $\epsilon$ найвищою цінністю сучасного суспільного прогресу i будь-якої контрольної діяльності. Виходячи з цього, цілком справедливо сучасними векторами функціонування інституту громадського контролю називають наступні ціннісні орієнтири: екзістенціально значущий порядок у суспільстві, зростання масштабу свободи соціальних суб'єктів, формування соціально-конструктивних світоглядних орієнтацій особистості, створення умов для розвитку ії ініціатив і реалізації творчих потенціалів [5, с. 30]. Відтак закономірно зароджується й утверджується тенденція поступального розвитку громадянського суспільства, зростає роль організації та самоорганізації у функціонуванні інституту громадського контролю, 
зміцнює вплив громадських форм контролю на всі сфери життєдіяльності громади.

3. Принципи громадянського контролю над діяльністю адміністративних судів. На нашу думку, ефективність громадянського контролю над діяльністю адміністративних судів забезпечується за умови неухильного дотримання наступних принципових вимог: контроль повинен бути об'єктивним та безстороннім (незалежним та неупередженим); він передбачає відкритість та прозорість, адже це основні вимоги до ефективності державної влади, сформованої демократичним шляхом; контроль має бути публічним та гласним, що передбачає доведення отриманої підсумкової інформації, результатів контролю, до громадськості та зацікавлених осіб; він повинен бути обгрунтованим та цілеспрямованим, що забезпечить його результативність, ефективність; науковість та професіоналізм як принципи громадського контролю передбачають залучення до здійснення контролю фахівців (правників, колишніх почесних суддів, науковців), що дозволить уникнути можливих зловживань, поверхневого підходу до контролю, забезпечить детальну та професійну оцінку роботи судді та прийнятих ним правозастосовних актів [6, с. 60-61]. Крім зазначених основних засад громадського контролю, важливе значення при його здійсненні має громадянська активність та незалежність суб'єктів контролю, відповідність їх дій чинному законодавству, справедливість і доведеність їх висновків, готовність до відповідальності за свої дії та рішення.

4. Форми i методи громадянського контролю над діяльністю адміністративних судів. Неможливо оминути увагою питання про форми i методи громадянського контролю над діяльністю адміністративних судів. Аналізуючи літературу з питань форм і методів контролю взагалі, можна відзначити, що в більшості випадків автори не надто переймаються розмежуванням цих понять, використовуючи їх сумісно (в кращому випадку) або називаючи інструментарієм, механізмом, системою контролю. Проте, на наше переконання, це суттєве питання, яке потребує свого визначення, адже ці поняття не тотожні і не взаємозамінні. Деякі науковці форми та методи контролю визначають як прийоми та способи [7]. Форма контролю вказує напрямок діяльності суб'єкта контролю для досягнення конкретної цілі, включаючи обрання тих чи інших методів. До того ж, методи при цьому можуть використовуватися різні, а їх обрання залежить не тільки від мети проведення контрольних дій, але й від інших обставин, від яких залежить ефективність проведення контролю як такого. Можна запропонувати наступні формулювання: метод громадського контролю судової влади - це спосіб, прийом, за допомогою якого можна оцінити результативність функціонування адміністративних судів; форма громадського контролю адміністративних судів може бути визначена як конкретне вираження і організація контрольних дій 3 метою оцінювання виконання судами своїх повноважень [8, с. 122]. 
5. Дієвість громадянського контролю над діяльністю адміністративних судів. Громадський контроль над діяльністю адміністративних судів сьогодні повинен передбачати наступне: публічність судових процесів, зокрема, 3 вільним доступом до них представників засобів масової інформації; можливість відводу суддів 3 ініціативи учасників судового процесу; включення в атестаційно-дисциплінарні органи (кваліфікаційні комісії суддів) представників юридичної громадськості, встановлення відповідальності за порушення суддівської дисципліни. Структурним елементом громадського контролю адміністративних судів, від якого значною мірою залежить його ефективність, а також важливим засобом комунікації між судовою владою і громадськістю є засоби масової інформації. Дієвість у реалізації громадського контролю в інших сферах довели такі форми співробітництва органів державної влади і громадськості як громадські ради. У науковій літературі громадські ради визначаються як певні утворення за участю представників громадськості, які мають формалізовану внутрішню структуру та певні повноваження, і з якими державні органи консультуються під час ухвалення та виконання державних рішень [9, с. 55-56]. Вони існують у вигляді публічного органу представництва громадськості, дорадчо-консультативного чи експертно-консультативного органу або поєднують представницькі та експертні функції.

6. Роль громадських рад при адміністративних судах у здійсненні громадянського контролю. Під консультативно-дорадчим органом у сучасній юридичній науці прийнято розуміти «колегіальну установу або орган, створені при органі публічної влади на постійній чи тимчасовій основі з метою забезпечення участі громадян в управлінні державними та суспільними справами шляхом проведення консультацій із громадськістю, попереднього обговорення питань, що належать до компетенції органу публічної влади, і здійснення громадського контролю за його діяльністю» [10, с. 143]. Громадські ради як консультативно-дорадчі органи при адміністративних судах дозволяють забезпечити участь громадян в управлінні державними справами, зокрема, у забезпеченні належних організаційних умов діяльності судів і суддів, утвердженні незалежності адміністративного суду, забезпеченні заборони втручання в діяльність судді щодо здійснення правосуддя, а також підвищенні рівня довіри суспільства до судової влади, налагодженні ефективної взаємодії органів судової влади 3 громадськістю, у врахуванні громадської думки підчас формування та реалізації державної судової політики. Ефективність і доцільність створення громадських рад підтверджується і світовою практикою їх функціонування.

Завданнями громадської ради $є$ наступне: створення умов для реалізації громадянами конституційного права на участь в управлінні державними справами у сфері судочинства 3 метою забезпечення права громадян на справедливий суд; здійснення громадського контролю за діяльністю органів суддівського самоврядування та участь юридичної громадськості у такій діяльності; сприяння врахуванню органами суддівського самоврядування думки юридичної громадськості під час формування та реалізації державної політики у сфері судочинства [11, с. 254]. 
Відповідно до цих завдань, громадська рада наділена такими повноваженнями: підготовка та подання Раді суддів України пропозицій до орієнтовного плану проведення консультацій з громадськістю, а також щодо проведення консультацій, непередбачених таким планом; підготовка та подання Раді суддів України пропозицій щодо організації консультацій 3 представниками юридичної громадськості; дослідження стану незалежності судової влади та діяльності органів суддівського самоврядування; аналіз та систематизація міжнародного досвіду у сфері незалежності судів та суддів; аналіз відповідності національного законодавства щодо судоустрою та статусу суддів міжнародним стандартам щодо незалежності, ефективності та ролі судів; збирання, узагальнення та подання до Ради суддів України інформації про пропозиції громадських організацій стосовно вирішення питань діяльності судової влади, зокрема, судової реформи, забезпечення незалежності судів та суддів, які мають важливе суспільне значення тощо; подання до Ради суддів України обов' язкових для розгляду пропозицій щодо підготовки проектів нормативно-правових актів, прийняття яких входить до компетенції Ради суддів України, та проектів рішень Ради суддів України 3 питань забезпечення належного функціонування органів судової влади, забезпечення незалежності судів та суддів, удосконалення роботи судів та органів суддівського самоврядування; проведення за зверненням Ради суддів України відповідно до законодавства громадської експертизи та громадської антикорупційної експертизи проектів нормативно-правових актів, прийняття яких входить до компетенції Ради суддів України, та проектів рішень Ради суддів України; здійснення громадського контролю за розглядом Радою суддів України пропозицій та зауважень громадськості; організація публічних заходів для фахового обговорення актуальних питань вдосконалення діяльності органів судової влади; надання за дорученням Ради суддів України науково-практичних рекомендацій 3 питань вдосконалення роботи органів судової влади та органів суддівського самоврядування, забезпечення незалежності судів та суддів, удосконалення законодавства про судоустрій та статус суддів; сприяння формуванню правової культури та правовій інформованості населення; сприяння поглибленню співпраці Ради суддів України з громадськими організаціями; інформування громадськості про свою діяльність, прийняті рішення та їх виконання на офіційному веб-сайті судової влади або в інший спосіб [12, с. 63-64].

До складу громадської ради можуть бути обрані представники юридичної громадськості, а саме: судді у відставці, працівники органів прокуратури у відставці, вчені-юристи, адвокати та інші особи, що мають вищу юридичну освіту, стаж роботи у галузі права та не перебувають на державній службі. Дійсно, на наш погляд, членами такої ради повинні бути, у першу чергу, шановані, авторитетні й незаангажовані фахівці в галузі права. Крім них, до складу такої організації доцільно включити громадських діячів, представників громадських об'єднань.

7. Неупередженість громадянського контролю над діяльністю адміністративних судів. Така громадська рада повинна працювати виключно колегіально 3 метою забезпечення неупередженості. Основними 
проблемами, які вбачаються у функціонуванні громадських рад загалом, $є$ відсутність законодавчої бази, що регулює їх діяльність, оскільки вказаного положення є явно недостатньо; неврегульованість фінансового забезпечення діяльності таких рад; потенційна можливість перетворення їх на «кишенькових» радників, тобто певна залежність їх від того органу, при якому вони створюються. Оскільки результатом суддівської роботи є судові, правозастосовні акти, то доречно говорити про доцільність застосування такої форми громадського контролю як аналіз винесених суддею рішень, їх відповідності принципам і нормам права, моральним засадам суспільства [13, с. 127]. Однак ця форма контролю може мати місце лише у виключних випадках. Можливо, критерієм іiі застосування буде кількість і зміст скарг щодо конкретного судді. Для цього варто створити процедуру їх фіксації в конкретному суді. Після того, як кількість скарг на суддю досягне встановленої межі, їх розглядатиме суб'єкт громадського контролю (можливо, громадська рада або спеціально створене громадське об'єднання всеукраїнського статусу, яке в разі необхідності може мати осередки в регіонах). Крім того, необхідно обміркувати можливість перегляду конкретного акту судді, відстороненого від посади в результаті рішення вказаного суб'єкта громадського контролю.

Важливо, що всі акти судді переглядати не має сенсу, та це й суперечить принципам права. Процедурні моменти застосування даної форми громадського контролю необхідно детально регламентувати в законодавстві, а також закріпити в статуті такого громадського об'єднання. Завдяки використанню такої форми громадського контролю, на наш погляд, вдасться мінімізувати прийняття неефективних рішень, підвищити рівень персональної відповідальності за них. Важливо підкреслити, що громадський контроль жодним чином не є знаряддям примусу, з його допомогою неможливо керувати, наказувати судовій владі здійснювати певні дії. Однак через використання різних форм громадського контролю можна звернути увагу держави на проблеми,недоліки в роботі судів, запобігти зловживанням, виявити некомпетентність. Громадський контроль можливий, перш за все, тоді,коли влада цього хоче або як мінімум, не перешкоджає. На сьогоднішній день, аналізуючи досвід співпраці інститутів громадянського суспільства 3 органами влади у сфері громадського контролю, слід констатувати наявність ряду проблем, що характерні для відносин між владою та громадськістю в Україні в цілому: традиції замкненості держапарату,непрозорість вироблення державної політики, взаємна недовіра, низький рівень громадської активності, низька ефективність громадських об'єднань та ін.

8. Тенденції розвитку громадянського контролю над діяльністю адміністративних судів. Потрібно відзначити і наявність певних позитивних зрушень, які свідчать про намагання влади подолати та вирішити ці проблеми. Так розроблено і прийнято за основу проект Закону України «Про інформаційну відкритість органів державної влади та вищих посадових осіб України», який визначатиме умови та порядок забезпечення інформаційної відкритості в питаннях діяльності органів державної влади та вищих посадових осіб України. Розроблені та очікують свого розгляду декілька 
проектів Закону України «Про громадський контроль», який регламентуватиме основні напрямки та форми громадського контролю. Доцільно, на наш погляд, у цьому Законі передбачити певні гарантії, які не дозволять судовим органам ухилятися від взаємодії 3 суб'єктами громадського контролю, закріпити відповідальність посадових осіб за протидіючи бездіяльність по відношенню до суб'єктів громадського контролю. Окрема глава такого закону повинна присвячуватися регламентації форм та меж громадського контролю судової влади.

Висновок. Отже, головним завданням будь-якого контролю є вплив на певний процес, у випадках коли він раптом йде не так, як потрібно. Контроль стає необхідним, якщо виникає несприятлива для механізму ситуація, що загрожує його руйнуванням або пошкодженням. Так, незважаючи на неприпустимість будь-якого втручання у справи адміністративних судів, в умовах недовіри громадськості до їх діяльності, контроль з боку народу над адміністративними судами стає необхідністю. Безперечно, існують деякі ризики щодо використання певних форм громадського контролю, однак попередити погіршення ситуації, збільшити довіру громадськості до судової влади, запобігти зловживанням, виявити некомпетентність, посилити персональну відповідальність суддів можна лише шляхом налагодження взаємодії адміністративних судів i громадськості, одним із напрямків якої $\epsilon$ застосування громадського контролю. Тож уцілому інституційна база громадського контролю адміністративних судів (об'єкти, суб'єкти, предмет та процедура) ще потребує свого подальшого наукового обгрунтування.

\section{Використані джерела:}

1. Кравчук В. Громадський контроль судової влади як спосіб відновлення довіри суспільства до судів та суддів. Актуальні проблеми правознавства. 2016. Вип. 3. С. 11-16.

2. Гоптарєв О. I. Громадський контроль за діяльністю судової влади на сучасному етапі. Науковий вісник Дніпропетровського державного університету внутрішніх справ. 2018. № 4. С. 66-69.

3. Нестерович В. Ф. Конституційно-правові засади здійснення впливу громадськості на прийняття нормативно-правових актів в Україні. Бюлетень Міністерства юстиції України. 2011. № 3. С. 32-41.

4. Олійник В. М. Громадський контроль за діяльністю органів судової влади: теоретико-правовий аспект. Науковий вісник Дніпропетровського державного університету внутрішніх справ. 2017. № 3. С. 88-94.

5. Жуков С. В. Елементний склад адміністративно-правового забезпечення доброчесності суддів. Європейські перспективи. 2019. № 1. С. 29-33.

6. Копетюк М. Адміністративний суд як суб'єкт адміністративного судочинства. Історико-правовий часопис. 2018. № 2. С. 58-62.

7. Нестерович В.Ф. Поняття форм впливу громадськості на прийняття нормативно-правових актів. Вісник Луганського державного університету внутрішніх спраһ імені Е.О. Дідоренка. 2016. № 2. С. 14-22.

8. Ковбасюк В. В. Шляхи розвитку та удосконалення правового регулювання відносин у сфері адміністративного судочинства. Науковi записки 
[Центтральноукраӥнського державного педагогічного університету імені Володимира Винниченка]. Серія : Право. 2018. Вип. 4. С. 122-126.

9. Кравчук В. Громадський контроль у функціонуванні судової влади. Вісник Національної академії прокуратури України. 2016. № 3. С. 53-60.

10. Нестерович В.Ф. Поняття «консультативно-дорадчий орган» як категорія конституційного права. Філософські та методологічні проблеми права. 2017. № 1. С. 138-145.

11. Лук'янець Д. М. Сучасні погляди на проблеми адміністративного судочинства. Право Украӥни. 2018. № 2. С. 253-256.

12. Коломоєць Т. О., Лютіков П. С. Оціночні поняття адміністративного судочинства України: наукові підходи до їх тлумачення у правовій доктрині. Право України. 2018. № 2. С. 54-70.

13. Олійник В. М. Громадський контроль за діяльністю органів судової влади: підходи до визначення поняття. Науковий вісник Дніпропетровського державного університету внутрішніх справ. 2017. № 1. С. 125-131.

\section{References}

1. Kravchuk V. (2016) Hromads'kyy kontrol' sudovoyi vlady yak sposib vidnovlennya doviry suspil'stva do sudiv ta suddiv [Public control of the judiciary as a way of restoring public confidence in courts and judges]. Aktual'ni problemy pravoznavstva. Iss. 3. S. 11-16. [in Ukrainian].

2. Hoptaryev O. I. (2018) Hromads'kyy kontrol' za diyal'nistyu sudovoyi vlady na suchasnomu etapi [Public control over the judiciary activity at the present stage]. Naukovyy visnyk Dnipropetrovs'koho derzhavnoho universytetu vnutrishnikh sprav. № 4 . S. 66- 69. [in Ukrainian]

3. Nesterovych V.F. (2011) Konstytutsiyno-pravovi zasady zdiysnennya vplyvu hromads'kosti na pryynyattya normatyvno-pravovykh aktiv v Ukrayini [Constitutional and legal bases of public influence on the adoption of normative legal acts in Ukraine]. Byuleten' Ministerstva yustytsiyi Ukrayiny. № 3. S. 32-41. [in Ukrainian]

4. Oliynyk V. M. (2017) Hromads'kyy kontrol' za diyal'nistyu orhaniv sudovoyi vlady: teoretyko-pravovyy aspect [Public control over the judiciary activity: theoretical and legal aspect]. Naukovyy visnyk Dnipropetrovs'koho derzhavnoho universytetu vnutrishnikh sprav. № 3. S. 88-94. [in Ukrainian]

5. Zhukov S. V. (2019) Elementnyy sklad administratyvno-pravovoho zabezpechennya dobrochesnosti suddiv [Elemental composition of administrative and legal support for judges integrity]. Yevropeys'ki perspektyvy. № 1. S. 29-33. [in Ukrainian]

6. Kopetyuk M. (2018) Administratyvnyy sud yak sub'yekt administratyvnoho sudochynstva [Administrative court as a subject of administrative proceedings]. Istorykopravovyy chasopys. № 2. S. 58-62. [in Ukrainian]

7. Nesterovych V.F. (2016) Ponyattya form vplyvu hromads'kosti na pryynyattya normatyvno-pravovykh aktiv [The concept of forms of influence of the public on the adoption of regulations]. Visnyk Luhans'koho derzhavnoho universytetu vnutrishnikh sprav imeni E.O. Didorenka. № 2. S. 14-22. [in Ukrainian]

8. Kovbasyuk V. V. (2018) Shlyakhy rozvytku ta udoskonalennya pravovoho rehulyuvannya vidnosyn u sferi administratyvnoho sudochynstva [Ways of development and improvement of legal regulation of relations in the field of administrative proceedings]. Naukovi zapysky Tsentral'noukrayins'koho derzhavnoho pedahohichnoho universytetu imeni Volodymyra Vynnychenka. Seriya: Pravo. Iss. 4. S. 122-126. [in Ukrainian]

9. Kravchuk V. (2016) Hromads'kyy kontrol' u funktsionuvanni sudovoyi vlady [Public control in the functioning of the judiciary]. Visnyk Natsional'noyi akademiyi prokuratury Ukrayiny. № 3. S. 53-60. [in Ukrainian] 
10. Nesterovych V.F. (2017) Ponyattya «konsul'tatyvno-doradchyy orhan» yak katehoriya konstytutsiynoho prava [The concept of "advisory body" as a katheory of constitutional law]. Filosofs'ki ta metodolohichni problemy prava. № 1. S. 138-145. [in Ukrainian]

11. Lukyanets' D. M. (2018) Suchasni pohlyady na problemy administratyvnoho sudochynstva [Contemporary views on the problems of administrative proceedings]. Pravo Ukrayiny. № 2. S. 253-256. [in Ukrainian]

12. Kolomoyets' T. O., Lyutikov P. S. (2018) Otsinochni ponyattya administratyvnoho sudochynstva Ukrayiny: naukovi pidkhody do yikh tlumachennya u pravoviy doktryni [Evaluation concepts of administrative proceedings in Ukraine: scientific approaches to their interpretation in legal doctrine]. Pravo Ukrayiny. № 2. S. 54-70. [in Ukrainian]

13. Oliynyk V. M. (2017) Hromads'kyy kontrol' za diyal'nistyu orhaniv sudovoyi vlady: pidkhody do vyznachennya ponyattya [Public control over the judiciary activity: approaches to the definition of the concept]. Naukovyy visnyk Dnipropetrovs'koho derzhavnoho universytetu vnutrishnikh sprav. № 1.S. 125-131. [in Ukrainian]

Стаття надіӥщла до редколегї̈ 18.06.2019

Кравченко И. Н., преподаватель кафедры общеправовых дисциплин Днепровского гуманитарного университета (г. Днепр, Украина)

\section{ПОНЯТИЕ И СОДЕРЖАНИЕ ОБЩЕСТВЕННОГО КОНТРОЛЯ НАД ДЕЯТЕЛЬНОСТЬЮ АДМИНИСТРАТИВНЫХ СУДОВ}

Статья посвящена анализу понятия, сущности и содержания общественного контроля как самостоятельного направления взаимодействия административных судов с общественностью. Рассматривается понятие общественного контроля над административными судами. Определены принципы осуществления общественного контроля над административными судами. Установлены формы осуществления общественного контроля над административными судами. Раскрыты методы проведения общественного контроля над административными судами. Выявлены проблемы осуществления общественного контроля над административными судами, а также предложены направления усовершенствования общественного контроля над административными судами.

Ключевые слова: административный суд, гражданское общество, общественный контроль. государственная власть, метод общественного контроля, судебная власть, форма общественного контроля

Kravchenko I., lecturer of the general legal sciences department of the Dnipro university of humanities

(Dnipro, Ukraine)

\section{CONCEPT AND CONTENT OF PUBLIC CONTROL OVER THE ACTIVITIES OF ADMINISTRATIVE COURTS}

The article deals with analysis of the concept, essence and content of public control as an independent direction of interaction between administrative courts and 
the public. The author has presented the concept of public control over administrative courts. The content of public control over the activity of administrative courts has been clarified. The range of subjects of public control over the activity of administrative courts has been outlined. The goals of public control over the activity of administrative courts have been revealed. The principles of exercising public control over the activity of administrative courts have been defined. Forms of exercising public control over the activity of administrative courts have been established. Methods of public control over the activity of administrative courts have been revealed. The issues of effectiveness of civil control over the activity of administrative courts have been considered. The role of public councils in administrative courts has been emphasized as a form of cooperation between stae authorities and the public in exercising civil control over the activity of administrative courts. The composition and powers of public councils at administrative courts in exercising civil control over the activity of administrative courts have been considered. The problematic issues of public control over the activity of administrative courts have been highlighted. The directions of improvement of public control over the activity of administrative courts have been determined. The author has proposed to provide for certain safeguards that will not allow the judicial authorities to evade interaction with public control entities, to hold officials liable for counteracting or inaction against public control entities.

Key words: administrative court, civil society, public control, state power, method of public control, judicial power, form of public control.

\section{DOI}

УДК 343.359.3(477)

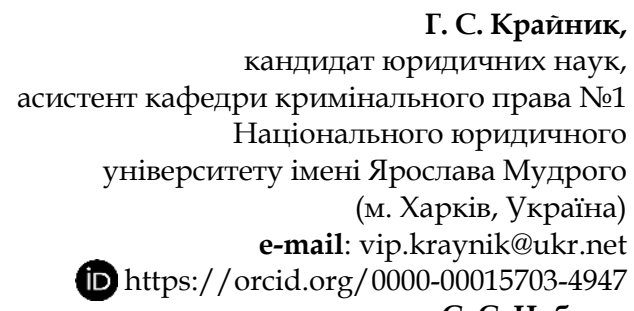

С. С. Чубарь,

студент 3 курсу 11 групи Інституту прокуратури та кримінальної юстиції Національного юридичного університету імені Ярослава Мудрого

(м. Харків, Україна)

e-mail: sergeychubar1502@gmail.com

(iD https://orcid.org/0000-0001-5626-7757

\section{ПИТАННЯ РЕФОРМУВАННЯ ВІДПОВІДАЛЬНОСТІ ЗА КОНТРАБАНДУ}

У статті досліджено актуальні питання щодо реформування відповідальності за контрабанду. Запропоновано законодавчі зміни до нової редакції Кримінального кодексу України та Кодексу України про адміністративні правопорушення, які належним чином врегулюють питання протидії контрабанді та усунуть існуючі недоліки. Обгрунтовано необхідність 